\title{
Occurrence of Suckermouth Armoured Sailfin Catfishes in Vellayani Fresh Water Lake, Kerala, Southwest Coast of India
}

\author{
Reenamole, G. R. ${ }^{1}$, Ambili, T. ${ }^{2}$ \\ Department of Zoology, Zoology Research Centre, F. M. N. C., University Of Kerala
}

\begin{abstract}
The sailfin catfish belonging to the genus Pterygoplichthys of the Loricariidae family has been widely introduced to tropical and subtropical freshwater environments worldwide. It caused serious ecological impacts. Vellayani Lake is the largest fresh water lake in Thiruvananthapuram district, and is the second largest fresh water lake in Kerala. About 42 species of freshwater fishes have been documented from the lake by various authors, primarily from the Department of Aquatic Biology and Fisheries, University of Kerala. A report on the occurrence of exotic South American suckermouth armoured catfish Pterygoplichthys pardalis (Castelnau, 1855), and Pterygoplichthys disjunctivus (Weber, 1991) from this lake is presented in this paper. Morphological study (Weber, 1991\& 1992 and Armbruster et al. 2006) was used for the fish identification.
\end{abstract}

Keywords: Suckermouth armoured catfish, Loricariidae, $P$. Pardalis, P. disjunctivus

\section{Introduction}

The sailfin catfish are among one of the exotic fish groups most seriously threatening tropical and subtropical freshwater regions have been introduced all around the world from South America by the aquarium trade. Nevertheless, occasional escapes due to carelessness of owners provided a chance for these fish to establish populations in tropical and subtropical freshwater bodies. South American suckermouth armoured catfishes (Loricariidae), are popular throughout the world as aquarium pets because of their characteristic attractive appearance and „use $\mathrm{e}^{\text {" }}$ in aquarium as a „cleaner" to remove the algae. The genus Pterygoplichthys is one of the fast dispersing species in the invaded countries, introduced primarily through uncontrolled pet trade and their invasion results in serious ecological and economic consequences (Nico et al. 2012). During the study period, from June 2013 to May 2015, a few specimens were collected from Vellayani Fresh water Lake. This study established the invasion of $P$. Pardalis, P. disjunctivus and their intermediates in this lake.

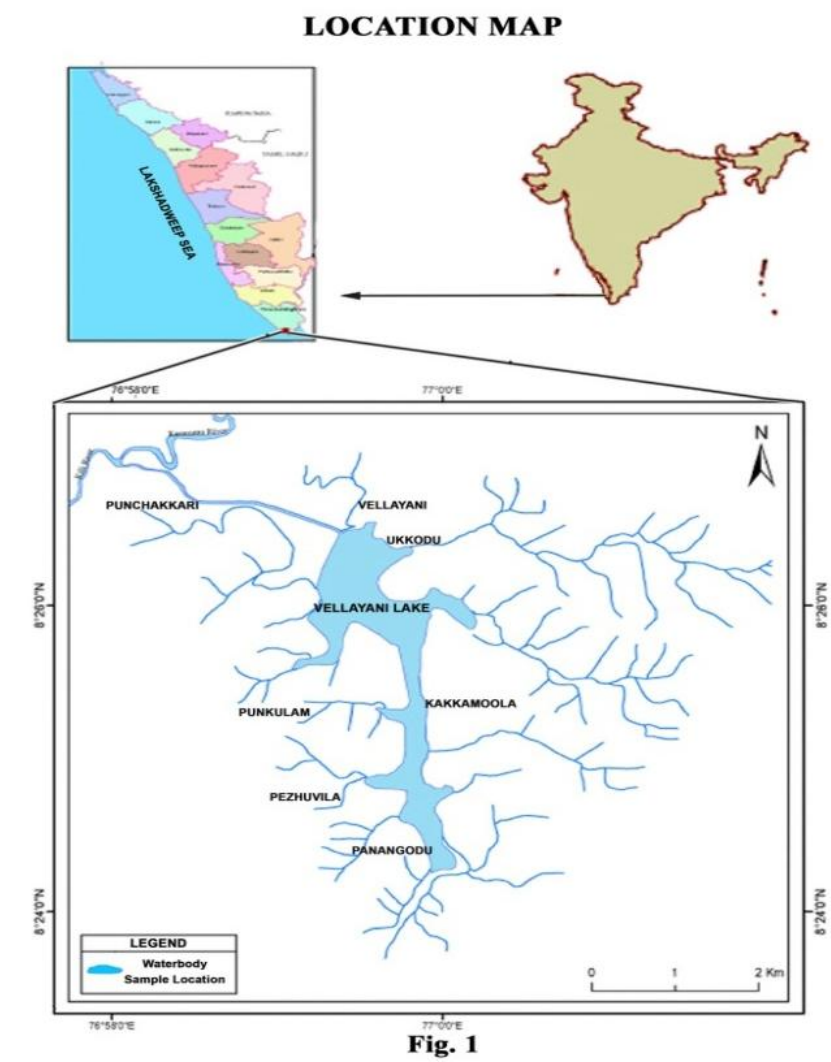

Figure 1: Map of the Vellayani Freshwater Lake

\section{Materials and Methods}

\subsection{Study Area}

The Vellayani Freshwater Lake $\left(8^{\circ} 24^{\text {"e }} 09^{\prime \prime}-8^{\circ} 26^{\text {"e }} 30^{\prime \prime} \mathrm{N}\right.$ and $76^{\circ} 59^{\prime \prime} 08^{\prime \prime}-76^{\circ} 59^{\circ "} 47^{\prime \prime}$ E) Thiruvananthapuram District in Kerala (Fig.1), is located $19 \mathrm{~km}$ away from the Thiruvananthapuram city. The Lake is situated 29 meters above mean sea level with a length of $3.15 \mathrm{~km}$ and width of $1 \mathrm{~km}$. The depth of the lake varies from 2 to $6 \mathrm{~m}$. The lake is a rich repository of flora and fauna which support the livelihood of local people around it. The livelihood of about 


\section{International Journal of Science and Research (IJSR) \\ ISSN (Online): 2319-7064 \\ Index Copernicus Value (2013): 6.14 | Impact Factor (2014): 5.611}

100 traditional fishermen depends on the fish resources of the lake. Vellayani Lake is an important wetland in south India used by waterfowls, both as feeding and breeding grounds.

\subsection{Sample Collection}

During a fish biodiversity survey of Vellayani Freshwater Lake, observed a few morphologically similar species from the suckermouth armored catfish of Loricariidae family, among the catches of local fishers. Samples were collected using „Pattu Valae, a type of seine net; during night. The specimens of this species were collected and brought to the Laboratory for taxonomic identification. Previously published descriptions of species and morphometric data were used to make comparison with the newly collected species. Specimens were identified based on the keys provided by Weber $(1991,1992)$ and Armbruster et al. (2006). The identified specimen is preserved at the Laboratory of the Fatima Mata National College, Kollam, under the University of Kerala.

\section{Results and Discussions}

According to Weber (1991, 1992) and Armbruster et al. (2006), the key characters of $P$. Multiradiatus has discrete dark spots on the lateral and caudal peduncle, never coalescing or forming chevrons. $P$. pardalis has dark spots on the lateral and caudal peduncle coalescing or forming chevrons, with ventral spots mostly discrete. $P$. disjunctivus has dark spots on the lateral and caudal peduncle coalescing or forming chevrons, while ventral spots coalesce to form vermiculations. As per the key, exotic individuals collecting from the lake were identified as P.pardalis (Castelnau, 1855), P.disjunctivus (Weber1991) and the intermediate forms of unknown identity (Fig.2 \& Fig.3).

Sailfin suckermouth catfishes (Pterygoplichthys spp.) are capable of surviving mesohaline conditions (up to $10 \mathrm{ppt}$ ) for extended periods of time, allowing for the use of estuarine and coastal areas for dispersal (Capps et al. 2011). South American suckermouth sailfin catfish Pterygoplichthys spp. have successfully invaded inland water bodies of various countries across the world, including Philippines, Japan, Taiwan, Vietnam, Sri Lanka, Indonesia, Malaysia and Singapore, Israel, Turkey, Bangladesh, Mexico, Europe and USA. In India, the suckermouth armoured catfishes reported the species of Pterygoplichthys anisitsi from Bihar, $P$. multiradiatus from Kerala and Tamil Nadu, $P$. disjunctivus and $P$. pardalis from Andhra Pradesh, West Bengal, Bihar and Uttar Pradesh. Recently, P.pardalis,
P.disjunctivus, and intermediary forms of unknown identity were recorded from the drainages of Thiruvananthapuram City, Kerala (Bijukumar et al.2015).

\section{Scientific Classification}

$\begin{array}{ll}\text { Kingdom } & \text { : Animalia } \\ \text { Phylum } & \text { : Chordata } \\ \text { Subphylum } & \text { : Vertebrata } \\ \text { Superclass } & \text { : Osteichthyes } \\ \text { Class } & \text { : Actinopterygii } \\ \text { Subclass } & : \text { Neopterygii } \\ \text { Infraclass } & \text { : Teleostei } \\ \text { Superorder } & \text { : Ostariophysi } \\ \text { Order } & : \text { Siluriformes } \\ \text { Family } & : \text { Loricariidae } \\ \text { Subfamily } & : \text { Hypostominae-armoredcatfishes } \\ \text { Genus } & : \text { Pterygoplichthys } \\ \text { Species } & : \text { 1 Pterygoplichthys pardalis } \\ \text { Common name } & : \text { Amazon sailfin catfish } \\ & \text { 2 Pterygoplichthys disjunctivus } \\ \text { Common Name } & : \text { Vermiculated Sailfin Catfish } \\ \text { Taxonomic status } & : \text { "valid" }\end{array}$

Pterygoplichthys pardalis (Castelnau, 1855) is a freshwater tropical fish in the armored catfish family, Loricariidae. It is one of a number of species commonly referred to as the common pleco or "leopard pleco" by aquarists. It will grow to a maximum length of 42.3 centimetres (16.7 in) SL. P.pardalis is sometimes confused with the Hypostomus plecostomus (another armored catfish known as the "common plecostomus"). The two species can be distinguished by their number of dorsal rays. $P$. pardalis has $11-13$, while the $H$. plecostomus has only 5-8 dorsal rays.

P.pardalis is native to the Amazon River Basin of Brazil and Peru. Although normally a bottomdwelling fish, they have the ability to breathe air from the surface of the water during dry periods and those in which dissolved oxygen is too low. There is also an albino color variation of this species, usually referred to as an "Albino Plecostomus". Synonyms are Hypostomus pardalis, Liposarcus pardalis, Liposarcus varius and Liposarcus jeanesianus.

P.disjunctivus is native to South America. Pterygoplichthys spp. are thought to create large, novel nutrient sinks in invaded streams. They sequester the majority of nitrogen and phosphorus of systems in their body armor. 


\section{International Journal of Science and Research (IJSR) \\ ISSN (Online): 2319-7064}

Index Copernicus Value (2013): 6.14 | Impact Factor (2014): 5.611

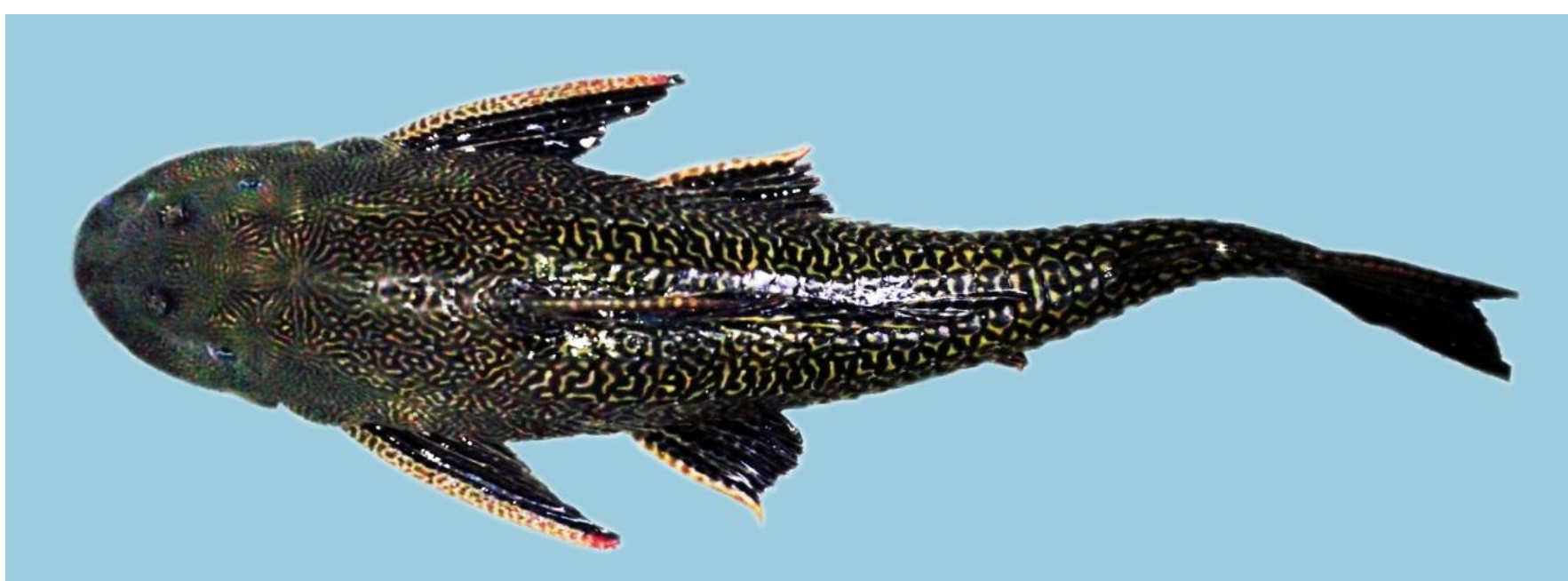

Figure 2: Pterygoplichthys Pardalis (Castelnau, 1855)

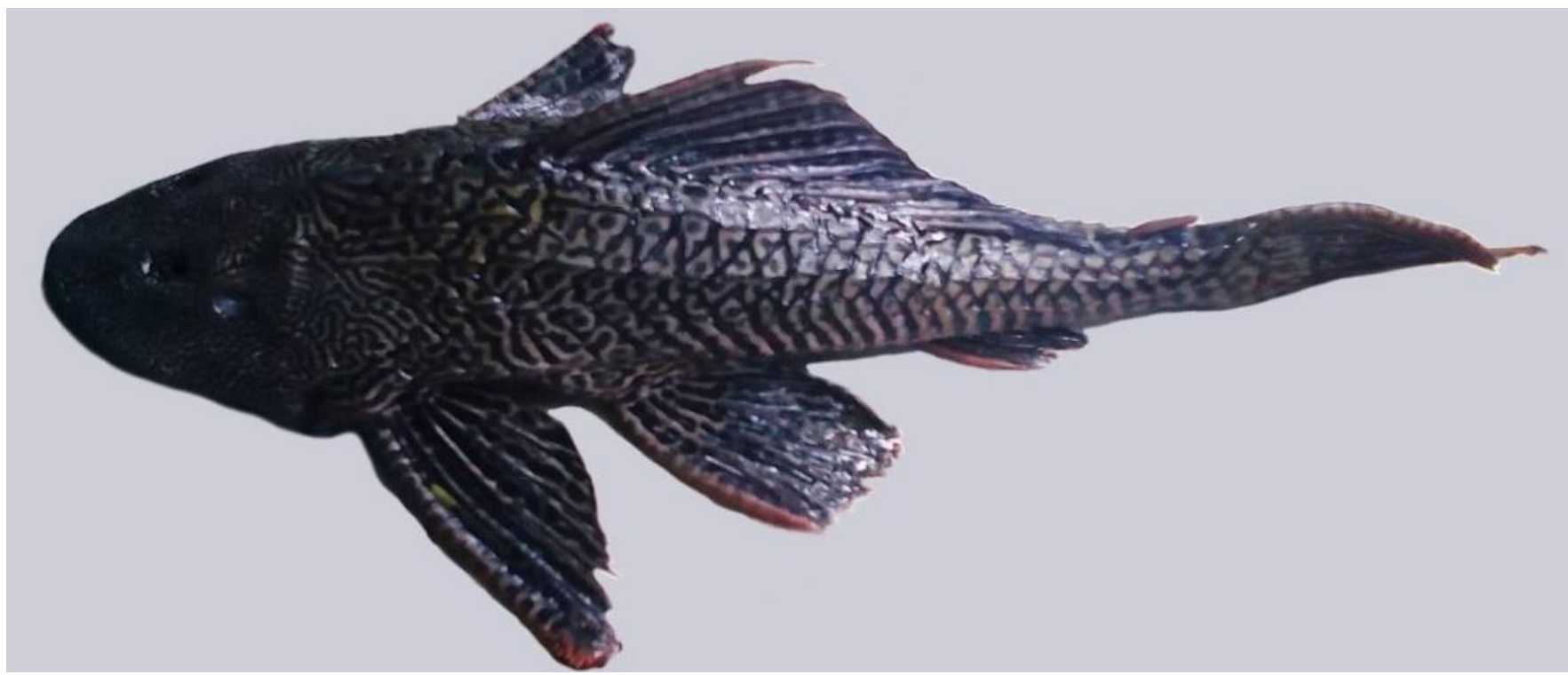

Figure 3: Pterygoplichthys disjunctivus (Weber, 1991)

Potential effects of Pterygoplichthys spp. include alteration of bank structure and erosion, disruption of aquatic food chains, competition with native species, mortality of endangered shore birds, changes in aquatic plant communities, and damage to fishing gear and industry. Environmental impacts of Pterygoplichthys spp. are not fully understood, but in locations where they are introduced and abundant, their feeding behaviours and burrowing activities can cause considerable disturbance. Their burrows have been reported as contributing to siltation problems and bank erosion and instability (Hoover et al. 2004).

The ability to withstand water pollution (Welcomme et al. 2003), toleration of poor oxygen content in water by means of accessory respiration with diverticula of the gastrointestinal tract (Armbruster 2006), lower number of predators and less vulnerability to predation due to spiny fins and hard external ,armoure (Zworykin et al. 2013), occasional migrations across land and low current velocity (Nico et al. 2012), peculiarities in reproduction and development such as prolonged reproductive period, batch spawning, development of eggs at very low water levels and active parental care (Hoover et al. 2004), coupled with greater feeding opportunities in smaller streams (Nico et al.
2012) help them to invade a variety of ecosystems and to establish successfully. A survey conducted among the ornamental fish traders and hobbyists in Thiruvananthapuram City revealed an interesting fact that when the specimens grow in size, the traders and hobbyists find it difficult to keep them in tanks and therefore release them into the natural drainages (Bijukumar, et al.2015).

In Vellayani Freshwater Lake, the intermediary forms of unknown identity are also present. There may be the possible hybridisation in this lake or the hybrids are released into the lake by the ornamental fish traders and hobbyists due to the unexpected or undesirable size growth of the fishes. To understand the possible threats due to invasion of Pterygoplichthys spp., the detailed study is need.

\section{Conclusion}

Pterygoplichthys spp. has damaged the fishing gear and gill nets in various locations. They have destroyed cages and nets. They were causing a decline in native, more desirable fishes in Laguna de Bay, Philippines. The effect of invading armoured catfishes on the indigenous fish stock in India is not clear. Vellayani Freshwater Lake is an important wetland 


\section{International Journal of Science and Research (IJSR) \\ ISSN (Online): 2319-7064 \\ Index Copernicus Value (2013): 6.14 | Impact Factor (2014): 5.611}

in south India used by waterfowls, both as feeding and breeding grounds. The livelihood of about 100 traditional fishermen depends on the fish resources of the lake. These fishes have damaged the fishing nets of fishermen in this lake also. Therefore, more systematic studies are warranted in this lake to document the impacts on indigenous species and environmental effects due to the invasion. To prevent the introduction of invasive species, need for legislation to the aquarium traders as a precautionary principle. Awareness about the ecological implications of these species, to the local people especially, aquarium hobbyists and fish breeders is one of the best way to prevent the invasion of unwanted species.

\section{References}

[1] A. Bijukumar, R. Smrithy, U. Sureshkumar \& S. George, 2015. Department of Aquatic Biology and Fisheries, University of Kerala, Thiruvananthapuram, Kerala 695581, India.

[2] Armbruster JW, LM Page. 2006. Redescription of $P$. punctatus and description of a new species of Pterygoplichthys (Siluriformes: Loricariidae). Neotrop. Ichthyol. 4: 401-409.

[3] Capps, K.A., L.G. Nico, M. Mendoza-Carranza, W. Arévlo-Frías, A.J. Ropicki, S.A. Heilpern, and R. Rodiles-Hernández. 2011. Salinity tolerance of nonnative suckermouth catfish in Mexico: Aquatic Conservtion: Marine and Freshwater Ecosystems 21:528540.

[4] Hoover, J.J., K.J. Killgore \& A.F. Cofrancesco (2004). Suckermouth catfishes: Threats to aquatic ecosystems of the United States. Aquatic Nuisance Species Research Bulletin 4: 1-8.

[5] Nico, L.G., P.L. Butt, G.R. Johnson, H.L. Jelks, M. Kail \& S.J. Walsh (2012). Discovery of the South American Suckermouth Catfish in the Santa Fe River drainage, USA. Bioinvasion Records 1: 179-200.

[6] Weber C. 1991. Nouveaux taxa dans Pterygoplichthys sensu lato (Pisces, Siluriformes, Loricariidae). Rev. Suisse Zool. 98: 637-643.

[7] Weber, C. (1992). Revision du genrew Pterygoplichthys sensu lato (Pisces, Siluriformes, Loricariidae). Revue Francaise d Aquariologie Herpetologie 19: 1-36.

[8] Welcomme, R. \& C. Vidthayanom (2003). The Impacts of Introductions and Stocking of Exotic Species in the Mekong Basin, Paper No. 9, Phnom Penh, 35pp.

[9] Zworykin, D.D. \& S.V. Budaev (2013). Non-indigenous armoured catfish in Vietnam: invasion and systematic. Ichthyological Research 60(4): 327-333;

\section{Author Profile}

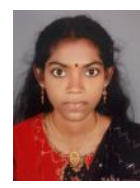

Reenamole.G.R received the B.Sc. degree in Zoology from H.H.M.S.P.B.N.S.S.College for Women, Neeramankara. B.Ed in Natural Science has taken from Govt. Anchal College, Kollam. M.Sc. degree in Zoology took from Mahatma Gandhi College, Thiruvananthapuram. M. Phil in Aquatic Biology and Fisheries from the Department of Aquatic Biology \& Fisheries in the University of Kerala, Kariavattom in 2012. All the degrees were received from the University of Kerala, Thiruvananthapuram, India. She has published 14 research papers and designed a text book of "Vellayani Fish Census- a Field Guide and Report" (Author: Dr. A. Biju Kumar \& Dr. Pramod Kiran R.B) published by Dept. of Aquatic Biology and Fisheries, University of Kerala and Supported by Agency of Development of Aquaculture, Kerala (ADAK) 2013. During 2008-2009, she worked as a Project Fellow in Central Marine Fisheries Research Institute in Vizhinjum, Thiruvananthapuram, Kerala, India. She now is doing Ph.D in Zoology at Zoology Research Centre, Department of Zoology, Fatima Mata National College, Kollam, University of Kerala, India.

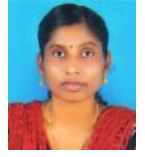

Ambili. T received the B.Sc. degree in Zoology from Sree Narayana Womens College, kollam. M.Sc. degree in Zoology from Fatima Mata National College,Kollam. B.Ed taken in Natural Science and awarded SET also. She has taken DCA. In 2012, she took M. Phil in Aquatic Biology and Fisheries from the Department of Aquatic Biology \& Fisheries in the University of Kerala, Kariavattom. All the degrees were received from the University of Kerala, Thiruvananthapuram, India. She has published 14 research papers. She now is doing Ph.D in Zoology at Zoology Research Centre, Department of Zoology, Fatima Mata National College, Kollam, University of Kerala, India. 